\title{
Kajian Pengaruh Heat Stress terhadap Beban Kerja Fisik Berat pada Kegiatan Lapangan
}

\author{
Caecilia Sri Wahyuning ${ }^{1 *}$, Diah Budi Laksemi ${ }^{2}$ \\ 1,2Program Studi Teknik Industri1, Institut Teknologi Nasional, Bandung, Indonesia
}

(*aecil@itenas.ac.id)

\begin{abstract}
Abstrak - Penelitian ini merupakan studi pendahuluan terhadap pengaruh tekanan panas terhadap beban kerja berat pada kegiatan lapangan, mengingat Indonesia sebagai negara tropis memiliki suhu dan kelembaban udara tinggi. Cuaca panas, yang dapat menyebabkan heat stress, merupakan beban bagi tubuh dan semakin berat pada aktivitas fisik berat. Eksperimen dilakukan terhadap 20 partisipan (10 orang pria, 10 orang wanita) yang melakukan pekerjaan dengan intensitas kerja tinggi selama 30 menit di lapangan dengan iklim ekstrim. Beban kerja dilihat berdasarkan denyut jantung dan berat badan untuk melihat energy expenditure, intensitas kerja, dan sweat rate. Hasil pengukuran menunjukkan beban kerja pada eksperimen ini termasuk dalam kategori tinggi/berat. Iklim lapangan diukur berdasarkan indeks WBGT, dan hasil pengukuran menunjukkan bahwa indeks WBGT selama eksperimen adalah $31^{\circ} \mathrm{C}\left(87.9^{\circ} \mathrm{F}\right)$, termasuk dalam kategori berisiko tekanan panas sangat tinggi. Hasil penelitian menunjukkan bahwa iklim tidak berpengaruh terhadap energy expenditure, akan tetapi berpengaruh terhadap energy expenditure pada partisipan wanita $(p<0.05)$. Iklim juga berpengaruh terhadap intensitas kerja $(p<0.05)$, sedangkan sweat rate tidak dapat digunakan untuk menghitung beban kerja karena waktu eksprimen tidak cukup meningkatkan panas tubuh dan hanya berdasarkan berat badan. Penelusuran lebih seksama terhadap model estimasi expenditure yang digunakan dalam sebuah eksperimen diperlukan agar sesuai dengan karakteristik pekerjaan.
\end{abstract}

Kata kunci: energy expenditure; heart rate; konsumsi oksigen; sweat rate; Wet Bulb Globe Temperature

\section{PENDAHULUAN}

Masalah pemanasan global akan berdampak pada aktivitas di luar ruangan, terutama di daerah panas. Suhu udara dan kelembaban udara yang tinggi sepanjang tahun merupakan ciri utama Negara Indonesia sebagai negara tropis. Kondisi seperti ini seharusnya menjadi perhatian, karena memperburuk kondisi kesehatan dan stamina tubuh. Permasalahan lain iklim kerja untuk aktivitas luar ruangan adalah paparan radiasi matahari yang dikombinasikan dengan aktivitas berat. Kontaminan fisik di tempat kerja akibat paparan panas yang menyebabkan tekanan panas (heat stress) tergantung pada durasi dan intensitas terpapar panas/dingin (Hajizadeh, dkk., 2016; Holmer \& Gahved, 2007). Kondisi ini membahayakan kesehatan dan keselamatan pekerja di tempat kerja, dan secara statistik banyak terjadi di negara-negara berkembang (Hajizadeh, dkk., 2016). Banyak kegiatan maupun pekerjaan yang harus dilakukan di luar dengan kondisi terpapar panas matahari contohnya seperti olah raga outdoor, bertani/ berkebun, pemetaan, pekerja konstruksi, pertambangan, pengeboran, dan kerja fisik lainnya. Perkerjaan ini termasuk dalam kategori overload medium/ menengah yaitu kondisi pekerjaan fisik berat dengan konsumsi energi yang tinggi (Søgaard \& Sjøgaard, 2015).

Sesaat setelah kerja fisik dilakukan, konsumsi energi (work joule) meningkat tajam, yang menunjukkan tingkat stres tubuh terutama pada pekerjaan berat. Selama tubuh terpapar tekanan panas, rata-rata kerja jantung meningkat (Kroemer, dkk., 2020; Wilson \& Crandall, 2011; Hunt, 2011), dan memungkinkan terjadi keringat berlebih, dehidrasi, dan serangan panas hingga pada kematian (Helander, 2006). Heat stress merupakan salah satu kondisi yang sering terjadi pada saat terpapar panas matahari, dan dapat berakibat gangguan fisiologis. Salah satu mekanisme fisiologis untuk mengatur suhu tubuh (termoregulasi) adalah penyesuaian fisiologis terhadap paparan panas. Dalam mengatasi paparan panas tubuh manusia menaikkan suhu kulit dan menjaga suhu intinya mendekati $37^{\circ} \mathrm{C}$, serta denyut jantung dan cardiac output (curah jantung) meningkat dan mengarahkan aliran sirkulasi darah ke kulit (Kraemer, dkk., 2020; Kroemer, dkk., 2020). Pada kondisi ini terjadi produksi dan penguapan keringat. Keseimbangan air dalam tubuh merupakan indikasi lain dari ketegangan panas (heat strain), kehilangan satu atau dua persen dari berat badan dapat mempengaruhi kemampuan tubuh untuk mengendalikan fungsinya (Kroemer, dkk., 2020).

Pengukuran sederhana detak jantung dapat berguna untuk memperkirakan jika ada masalah dengan tingkat beban kerja fisik (Helander, 2006). Denyut jantung (indikator utama fungsi peredaran darah) dan konsumsi oksigen (mewakili konversi metabolik) memiliki hubungan linier dan andal dalam rentang antara pekerjaan 
ringan dan berat (Kroemer, dkk., 2020), semakin tinggi beban kerja membutuhkan konsumsi energi lebih besar. Konsumsi energi hanya mengukur tingkat upaya fisik tanpa memberikan gambaran tentang tekanan mental, tuntutan pekerjaan dan masalah fisik (Kroemer \& Grandjean, 2009), sedangkan dalam menghadapi tekanan panas denyut jantung dan cardiac output meningkat (Kraemer, dkk., 2020; Kroemer, dkk., 2020). Oleh karena itu pada penelitian ini akan dikaji seberapa besar paparan panas berpengaruh terhadap beban kerja fisik pada kegiatan di luar ruangan dengan radiasi matahari.

\section{STUDI LITERATUR}

\section{A. Beban Kerja Fisik}

Beban kerja merupakan besarnya tuntutan pekerjaan yang membebani manusia, begitu beban kerja dengan tenaga fisik selesai, konsumsi energi akan meningkat drastis, peningkatan konsumsi dinyatakan dalam joule kerja (work joule). Beban kerja dapat diterima bila beban kerja tersebut seimbang dengan kapasitas kardiorespirasi selama 8 jam kerja. Pada kondisi mendekati seimbang, pengambilan oksigen $\left(\mathrm{VO}_{2}\right)$ dan detak jantung (Heart Rate/ HR) akan mempertahankan tingkat kondisi stabil dengan output kerja yang konstan (Wu \& Wang, 2002).

Semakin besar kebutuhan otot dalam aktivitas manusia, semakin banyak energi yang dikonsumsinya. Joule kerja diperoleh dengan mengukur konsumsi energi saat bekerja dan mengurangi konsumsi istirahat atau metabolisme basal. Joule kerja menunjukkan tingkat stres tubuh, terutama dalam pekerjaan berat. Konsumsi energi hanya mengukur tingkat upaya fisik, yang digunakan sebagai ukuran perbandingan hanya untuk usaha fisik yang berat dan bukan untuk mempelajari aktivitas mental atau pekerjaan terampil (Kroemer \& Grandjean, 2009).

Denyut jantung (HR, juga disebut denyut nadi) seringkali dapat dengan mudah menggantikan pengukuran proses metabolisme, terutama $\mathrm{O}_{2}$ uptake. Pengukuran sederhana detak jantung dapat berguna untuk memperkirakan jika ada masalah dengan tingkat beban kerja fisik, HR dan variabilitasnya (HRV) merupakan metode yang sering digunakan untuk mengevaluasi beban kerja (Wahyuning, dkk., 2017) karena denyut jantung merespons perubahan tuntutan pekerjaan lebih cepat, sehingga lebih mudah mencerminkan respons tubuh terhadap perubahan kebutuhan kerja (Kroemer, dkk., 2020). Akan tetapi, walaupun ukuran ini yang jauh lebih mudah, detak jantung adalah prediktor yang baik hanya untuk beban kerja dengan intensitas sedang (sekitar 100-140 detak/ menit) (Helander, 2006).

Penelitian ini akan melakukan penilaian terhadap beban fisik melalui pengukuran detak jantung partisipan. Kriteria fisiologis yang paling umum digunakan untuk evaluasi beban fisik adalah konsumsi energi selama pembebanan dan konsumsi oksigen (Dempsey, 1998 dalam Roja, dkk., 2019). Kondisi pandemik menyebabkan kegiatan penelitian sangat dibatasi. Penelitian tidak dapat dilakukan di laboratorium dan adanya pembatasan interaksi antara peneliti dan partisipan menyebabkan untuk kontak fisik dan menjaga jarak. Kondisi ini menyebabkan variabel prediktor yang dapat dikumpulkan pun terbatas, sehingga variabel yang dikumpulkan hanya berat badan dan denyut jantung. Kamalakannan, dkk. (2007) mengembangkan model estimasi beban kerja berdasarkan denyut jantung dan karakteristik fisik, namun demikian pengukuran tinggi badan, sebagai salah satu variabel prediktor, tidak dapat diperoleh. Oleh karena itu, persamaan yang digunakan untuk menentukan beban kerja fisik adalah model kedua konsumsi energi yang dikembangkan oleh Keytel, dkk., (2005) yang tidak mempertimbangkan tinggi badan dalam modelnya, yaitu:

$$
\underset{\mathrm{kJ} / \mathrm{mnt}}{\mathrm{EE}}=\underset{0.55 .0969}{\mathrm{G}}+0.630 \mathrm{HR}+0.1988 \mathrm{~W}+0.2017 \mathrm{~A})+(1-\mathrm{G})(-20.4022+0.4472 \mathrm{HR}-0.1263 \mathrm{~W}+0.0074 \mathrm{~A})
$$

dengan: HR : denyut jantung (beat/ menit) $\mathrm{W}$ : berat badan $(\mathrm{kg})$
A : usia (tahun)

$\mathrm{G}$ : gender dengan nilai 1 untuk pria dan 0 untuk wanita

Persamaan yang digunakan untuk menentukan konsumsi oksigen $\left(\mathrm{VO}_{2}\right)$ mengacu pada heart rate yang telah dikembangkan oleh Yuliani (2010) (Iridiastadi \& Yassierli, 2014) yaitu:

$$
\begin{aligned}
& \mathrm{VO}_{\text {pria }}=-1,168+0,020 \mathrm{HR}-0,035 \mathrm{~A}+0,019 \mathrm{~W} \text { (liter/menit) } \\
& \mathrm{VO}_{\text {wanita }}=-1,991+0,013 \mathrm{HR}+0,024 \mathrm{~W} \text { (liter/menit) }
\end{aligned}
$$


dengan: HR : denyut jantung (beat/menit)

$$
\begin{aligned}
& \mathrm{A}: \text { usia (tahun) } \\
& \mathrm{W}: \text { berat badan }(\mathrm{kg})
\end{aligned}
$$

Mengingat bahwa aktivitas yang dilakukan merupakan aktivitas fisik secara dinamis, maka indeks beban kerja yang digunakan adalah $\% \mathrm{VO}_{2} \max$, relative heart rate (RHR) dan relative oxygen uptake $\left(\mathrm{RVO}_{2}\right)$. $\% \mathrm{VO}_{2 \max }$ sebagai indeks kapasitas aerobik maksimum mencerminkan intensitas beban kerja. Berdasarkan Persamaan (Swain, dkk., 1994). \% $\mathrm{VO}_{2 \max }$ tersebut didefinisikan sebagai:

$$
\% \mathrm{VO}_{2 \max }=\frac{\left.\left(\frac{\mathrm{HR}_{\mathrm{work}}}{\mathrm{HR}}\right) \times 100-37\right)}{0.64}
$$

RHR (atau HRR, heart rate reserve) merupakan intensitas kerja berdasarkan persentase perbedaan antara $\mathrm{HR}_{\text {work }}$ dan $\mathrm{HR}_{\text {maz }}$ terhadap $\mathrm{HR}_{\text {rest }}$. $\mathrm{HR}_{\text {max }}$ menggambarkan kapasitas transport oksigen maksimal individu (Rodahl, 1989), denyut jantung lebih dari 100 denyut/ menit mencerminkan kelebihan beban sistem kardiovaskular untuk kerja dinamis (Bedny, dkk., 2001). RHR didefinisikan sebagai:

$$
\text { RHR }=\frac{(\text { HRwork }- \text { HRrest })}{(\text { HRmax }- \text { HRrest })} \times 100 \%
$$

dengan: $\mathrm{HR}_{\max }$ : maximum heart rate yang ditetapkan berdasarkan persamaan regresi untuk memprediksikan $\mathrm{HR}_{\max }$ pada individu dewasa sehat (Tanaka, dkk., 2001):

$\mathrm{HR}_{\max }=208-0.7$ (usia)

$\mathrm{HR}_{\text {rest }}$ : resting heart rate level

$\mathrm{HR}_{\text {work }}$ : rata heart rate selama bekerja

Serupa dengan RHR demikian pula dengan $\mathrm{RVO}_{2}$ yang didefinisikan sebagai:

$$
\mathrm{RVO}_{2}=\frac{\left(\mathrm{VO}_{2_{\text {work }}}-\mathrm{VO}_{2_{\text {rest }}}\right)}{\left(\mathrm{VO}_{2_{\text {max }}}-\mathrm{VO}_{2_{\text {rest }}}\right.} \times 100 \%
$$

Berkeringat adalah salah satu metode pengaturan suhu tubuh yang mengandalkan penguapan keringat untuk meningkatkan kehilangan panas tubuh (Fan, Zhao, Luo, \& Zhang, 2019)). Pengukuran sweat rate merupakan salah satu cara dalam menentukan tingkat beban kerja, metode paling sederhana dan akurat untuk menilai sweat rate yaitu melalui perubahan massa tubuh selama beraktivitas dibandingkan dengan waktu/ durasi pengumpulan keringat (Baker, 2017). Pengukuran sweat rate (SR) ini dengan mengukur berat badan sebelum melakukan aktivitas dan setelah melakukan aktivitas. Berat badan sebagai input untuk perhitungan whole body sweat rate dengan satuan $\mathrm{kg} / \mathrm{jam}$.

\section{B. Tekanan Panas}

Wet Blube Globe Temperature (WBGT) Index atau Indeks Suhu Bola Basah (ISSB) merupakan indeks untuk mengevaluasi heat stress (tekanan panas), yaitu sebagai salah satu indeks stres panas kerja yang paling banyak digunakan di seluruh dunia dan dimasukkannya dalam standar internasional (ISO 7243) dan nasional (American Conference of Govermental Industrial Hygienist, 2009; Gao, dkk., 2018). Tekanan panas atau heat stress menurut ACGIH (2009) adalah beban bersih panas yang diterima oleh tenaga kerja yang merupakan kombinasi dari gabungan panas metabolisme, faktor lingkungan (meliputi suhu udara, kelembaban udara, kecepatan udara, dan panas radiasi), dan jenis pakaian kerja yang digunakan.

\section{Mekanisme Tubuh Terhadap Tekanan Panas}

Terdapat beberapa mekanisme fisiologis untuk mengatur suhu tubuh, yang dikenal sebagai termoregulasi. Penyesuaian kardiovaskular merupakan awal dari mekanisme tubuh memulai pertahanannya terhadap panas tubuh, respon sirkulasi (peredaran darah) terhadap panas terkait dengan penyesuaian fisiologis terhadap paparan panas. Panas meningkatkan denyut jantung dan cardiac output (curah jantung) dan mengarahkan 
aliran sirkulasi, sehingga dapat menurunkan panas, seiring dengan peningkatan keringat sebagai tanda upaya tubuh menghilangkan panas (Kraemer, dkk., 2012). Saat terkena pemanasan impuls saraf dari reseptor menuju tulang belakang dan memberikan informasi ke hipotalamus (pusat kendali termoregulasi), seluruh tubuh manusia harus menjaga suhu intinya mendekati $37^{\circ} \mathrm{C}$ (Hunt, 2011; Kroemer, 2020). Hipotalamus merespon adanya kelebihan panas yaitu dengan cara menaikkan suhu kulitnya, membawa panas melalui aliran darah menuju kulit, sehingga rata-rata tekanan arteri pulmonalis menurun, aliran darah meningkat dan mempercepat detak jantung serta memperbesar curah jantung (Kroemer, 2020; Wilson \& Crandall, 2011; Hunt, 2011). Dengan demikian maka tekanan panas meningkatkan suhu inti tubuh serta kerja jantung.

\section{METODOLOGI}

\section{A. Desain Eksperimen}

Penelitian ini akan mengkaji pengaruh paparan panas terhadap beban kerja fisik saat bekerja di lingkungan luar (outdoor) yang panas dengan radiasi matahari. Mengingat kondisi pandemic Covid-19 yang terjadi saat ini, tidak memungkinkan untuk melakukan penelitian terhadap pekerjaan-pekerjaan di luar ruangan. Oleh karena itu untuk stimulasi detak jantung dan keringat untuk mendapatkan pekerjaan dengan beban kerja sedang-berat dilakukan aktivitas yang menimbulkan beban kerja sedang-tinggi di luar ruangan dengan thermal (heat) stress di lapangan, dalam waktu terbatas.

Pembatasan kegiatan menyebabkan percobaan dilakukan di lapangan olah raga, yang dilakukan pada siang hari dengan waktu pengamatan dimulai pukul 10.00-14.50 WIB., dengan asumsi pada jam ini paparan panas di yang terjadi mewakili iklim kerja lapangan di Indonesia. Aktivitas yang dilakukan adalah berlari dengan intensitas sedang-tinggi, dengan HR di atas $100 \mathrm{bpm}$. Berlari merupakan kegiatan yang melibatkan sebagian besar otot tubuh serta, sehingga dapat mensimulasikan pekerjaan fisik yang umum dilakukan di lapangan seperti kerja konstruksi, petani, dan sebagainya. Keterbatasan waktu dan pembatasan jumlah partisipan di lapangan menyebabkan hanya dapat dilakukan selama 30 menit per partisipan, sehingga diasumsikan waktu 30 menit sudah dapat mencapai intensitas kerja sedang-tinggi yang menggambarkan peningkatan beban kerja. Pengukuran detak jantung diperlukan untuk memperoleh nilai $\mathrm{HR}_{\text {rest }}$ dan $\mathrm{HR}_{\text {work }}$. Alat yang digunakan adalah heart rate monitor yang terdapat pada pulse oxymeter. Nilai indeks WBGT menggunakan heat stress WBGT meter Extech HT30. Pengukuran dilakukan setiap 10 menit selama kegiatan berlangsung, sedangkan berat badan diukur sebelum dan setelah menjalankan aktivitas. Selama percobaan partisipan dan peneliti tetap menerapkan protokol kesehatan.

\section{B. Partisipan}

Jumlah partisipan pada penelitian ini sebanyak 30 orang yang terdiri dari mahasiswa dan mahasiswi dengan rentang usia 21-22 tahun. terdiri dari 15 orang pria dan 15 orang wanita. Partisipan bukan atlet namun terbiasa melakukan olahraga di luar ruangan (pada pagi hari) sehingga partisipan dalam kondisi belum teraklimatisasi untuk kondisi panas dan diasumsikan dalam keadaan sehat. Pada kondisi heat stress, individu yang belum teraklimatisasi memiliki heart rate lebih tinggi daripada yang sudah teraklimatisasi (Konz \& Johnson, 2008). Selain itu penelitian ini tidak mempertimbangkan Syndrome of Iinappropriate Antidiuretic Hormone Secretion (SIADH) yang dapat mempengaruhi nilai tingkat penguapan pada partisipan.

\section{Analisis Statistik}

Kondisi pandemi menyebabkan peneliti kesulitan untuk mendapatkan relawan sebagai partisipan, oleh karena itu tidak dilakukan estimasi ukuran sampel formal. Karakteristik partisipan akan dianalisis dengan statistik deskriptif, rata-rata ( \pm standar deviasi). Pengujian statisik menggunakan SPSS, uji statistik Kolmogorov-Smirnov untuk uji kenormalan data HR dan SR, sedangkan mengetahui perbedaan sebelum dan sesudah beraktivitas dilakukan uji T berpasangan 2 sisi. Tujuan penelitian ini adalah untuk melihat pengaruh iklim pada pekerjaan dengan beban kerja sedang-tinggi serta uji korelasi Pearson dengan taraf signifikansi $\alpha$ $=0.05$. 


\section{HASIL DAN DISKUSI}

Berdasarkan hasil pengukuran, diperoleh rata-rata indeks WBGT selama pengukuran adalah $31^{\circ} \mathrm{C}$ dengan rentang $29.8^{\circ} \mathrm{C}-33.7^{\circ} \mathrm{C}$. Rata-rata Index WBGT antara pukul 10.00, pukul 12.00, dan pukul 14.50 adalah $29,8^{\circ} \mathrm{C} ; 31,0^{\circ} \mathrm{C}$; dan $32,8^{\circ} \mathrm{C}$. Berdasarkan prakiraan cuaca untuk hari pengukuran kecepatan udara sekitar 15 $\mathrm{km} / \mathrm{jam}$ dan kelembaban antara $80 \%$.

Karakteristik partisipan berdasarkan hasil pengukuran dapat dilihat pada Tabel 1. Usia partisipan 21-23 tahun, sehingga mengacu pada Tanaka (2001) maka rata $\mathrm{HR}_{\max }$ partisipan adalah 192, $58 \mathrm{bpm}$ (190.5 bpm$193.3 \mathrm{bpm})$, sedangkan rata-rata $\mathrm{HR}_{\text {rest }}$ adalah $74.87 \mathrm{bpm}(70 \mathrm{bpm}-82 \mathrm{bpm})$. Dari hasil pengukuran diperoleh rata- rata $\mathrm{HR}_{\text {work }}$ adalah $154,33 \mathrm{bpm}(147.0 \mathrm{bpm}-158.8 \mathrm{bpm})$, oleh karena itu partisipan mengalami peningkatan kerja selama beraktivitas. Kondisi ini menunjukkan bahwa intensitas kerja partisipan berada pada intensitas tinggi, karena kriteria intensitas kerja sedang denyut jantung berkisar antara 100-140 bpm (Helander, 2006). Denyut jantung merespons perubahan tuntutan pekerjaan lebih cepat, sehingga lebih mudah mencerminkan respons tubuh terhadap perubahan kebutuhan kerja (Kroemer, dkk., 2020).

Tabel 1

Karakteristik partisipan (rata-rata \pm SD)

\begin{tabular}{|c|c|c|c|c|c|c|}
\hline & \multirow{2}{*}{$\begin{array}{c}\text { Usia } \\
\text { (tahun) }\end{array}$} & \multicolumn{3}{|c|}{ Heart Rate (bpm) } & \multicolumn{2}{|c|}{ Berat Badan (kg) } \\
\hline & & $\operatorname{Max}$ & Rest & Work & Sebelum & Sesudah \\
\hline $\begin{array}{l}\text { Seluruh partisipan } \\
\qquad(\mathrm{n}=30)\end{array}$ & $22.03 \pm 0.72$ & $192.58 \pm 0.5$ & $74.87 \pm 3.43$ & $154.33 \pm 2.97$ & $63.47 \pm 10.16$ & $63.21 \pm 10.16$ \\
\hline Pria $(n=15)$ & $22.20 \pm 0.86$ & $192.46 \pm 0.60$ & $74.87 \pm 3.48$ & $155.40 \pm 2.26$ & $69.32 \pm 9.77$ & $69.05 \pm 9.74$ \\
\hline Wanita $(n=15)$ & $21.87 \pm 0.52$ & $192.69 \pm 0.36$ & $74.87 \pm 3.50$ & $153.38 \pm 3.28$ & $57.63 \pm 6.73$ & $57.37 \pm 6.79$ \\
\hline
\end{tabular}

Uji kenormalan menunjukkan data HR berdistribusi normal, dan terdapat perbedaan HR sebelum dan setelah menjalankan kegiatan $(\mathrm{p}<0.05)$. Pekerjaan berat adalah aktivitas yang membutuhkan pengerahan tenaga fisik dan ditandai dengan konsumsi energi tinggi serta tekanan pada jantung dan paru-paru (Kroemer \& Grandjean, 2009). Uji statistik menunjukkan tidak terdapat perbedaan sweat rate sebelum dan setelah menjalankan kegiatan $(\mathrm{p}>0,05)$, dengan demikian beban kerja tidak dapat dilihat dari sweat rate. Waktu 30 menit beraktivitas tidak cukup meningkatkan suhu tubuh inti, sehingga tidak ada respon dari termoreseptor pusat dan kulit yang memerintahkan hipotalamus preoptik otak untuk merangsang keringat dan vasodilatasi kulit untuk menghilangkan panas. Selain itu, parameter berat badan saja tidak cukup memadai untuk mengukur sweat rate. Pada beberapa penelitian, pengukuran sweat rate mempertimbangkan hydration status, menggunakan teknik gravimetry megngunakan filter paper, absorbent patches, Parafilm-M pouches, sarung tangan karet/ cotton, atau plastic sweat collectors (Baker, 2017), berat badan berpakaian, pakaian dan sepatu, dan makanan/minuman (Smith, dkk., 2021). Tabel 2 menunjukkan beban kerja fisik dari hasil percobaan.

Tabel 2

Beban kerja fisik berdasarkan heart rate

\begin{tabular}{cccc}
\hline & Seluruh partisipan $(\mathrm{n}=30)$ & Pria $(\mathrm{n}=15)$ & Wanita $(\mathrm{n}=15)$ \\
\hline Energy Expenditure (kJ/ menit) & $49.73 \pm 7.38$ & $56.96 \pm 2.50$ & $42.51 \pm 1.50$ \\
$\mathrm{VO}_{2 \max }$ (liter/ menit) & $2.3 \pm 0.22$ & $2.47 \pm 0.19$ & $2.22 \pm 0.16$ \\
\%VO 2 max & $67.41 \pm 2.52$ & $68.35 \pm 2.04$ & $66.47 \pm 2.67$ \\
Relative HR \& Relative VO2 & $67.48 \pm 2.82$ & $68.48 \pm 2,06$ & $66.49 \pm 3.18$ \\
Sweat Rate (Kg/menit) & $0.009 \pm 0.004$ & $0.009 \pm 0.004$ & $0.009 \pm 0.004$ \\
\hline
\end{tabular}

Aktivitas ini termasuk dalam pekerjaan yang melibatkan seluruh anggota tubuh. Rata-rata konsumsi energi untuk seluruh partisipan, partisipan pria dan wanita lebih dari $42 \mathrm{~kJ} /$ menit, sehingga bila mengacu pada hasil pemodelan beban kerja petani yang dikembangkan oleh Pawlak \& Maksym (2018), maka aktivitas ini termasuk aktivitas yang sangat berat $(35.6 \mathrm{~kJ} / \mathrm{min}-48.2 \mathrm{~kJ} / \mathrm{min})$.

Rata-rata konsumsi oksigen untuk seluruh partisipan maupun partisipan pria dan wanita selama beraktivitas, lebih dari $2 \mathrm{~L} / \mathrm{min}$. Aktivitas dengan konsumsi oksigen 2.0-2.5 L/min termasuk dalam kategori beban kerja sangat tinggi (Grandjean dan Kroemer, 2009). 
RHR sering digunakan sebagai indikator beban kerja fisik yang terkait dengan kerja otot dinamis dan menunjukkan ketersediaan beat per minute (bpm) dari istirahat sampai kerja (Pettitt, dkk., 2007). Rata-rata $\mathrm{RVO}_{2}$ dan RHR di atas 66\%, hal ini menunjukkan bahwa beban aktivitas tersebut tinggi. Secara umum aktivitas yang dilakukan pada RHR atau $\mathrm{RVO}_{2} \geq 30 \%$ dapat dipertimbangkan sebagai beban kardiovaskular (CVL) tinggi untuk 8 jam kerja (Wu \& Wang, 2002), dan RHR 60-84\% terjadi pada aktivitas dengan intensitas berat (hard) (Pettitt, dkk., 2007). Oleh karena itu simulasi aktivitas kerja ini menghasilkan beban kerja yang besar, yang menggunakan $70 \%-89 \% \mathrm{HR}_{\max }$.

Penurunan berat badan terjadi akibat evaporasi/ penguapan pada tubuh. Perubahan fase ini terjadi karena panas dan energi diekstraksi dari tubuh, yang kemudian mendinginkannya (Kroemer \& Grandjean, 2009). Rata-rata berat badan partisipan sebelum dan setelah aktivitas adalah $63.5 \mathrm{~kg}$ dan $63.2 \mathrm{~kg}$, dan rata-rata nilai sweat rate sebesar $0.009 \mathrm{~kg} /$ menit (dengan asumi $1 \mathrm{~kg}=11 \mathrm{t}$ ). Hal yang ingin diketahui dari penelitian ini adalah keterkaitan antara iklim dan beban kerja. Hasil pengujian statistik (Tabel 3) menunjukkan bahwa tidak terdapat korelasi antara iklim dengan beban kerja yang dilihat dari energy expenditure. Akan tetapi bila melihat gender, maka terdapat korelasi antara iklim dengan energy expenditure pada partisipan wanita, pola denyut jantung ini bervariasi antar individu, dipengaruhi oleh faktor genetis, usia dan lingkungan (Wahyuning, Salami, \& Sutalaksana, 2017). Enery expenditure harian harian merupakan gabungan nilai Basic Metabolic Rate (BMR), Thermic effect of feeding (TEF), dan thermic effects of activity (TEA), dengan komposisi 60\%-75\% BMR, 15\%-30\% TEA, dan sekitar 10\% TEF. Pada umumnya, jenis dan massa jaringan dan sel yang berbeda mempengaruhi kebutuhan energi serta tingkat hormon, sehingga BMR dan DEE dapat sangat bervariasi antara jenis kelamin, usia yang berbeda, dan individu (Gunga, 2021).

Terdapat hubungan linier antara HR dan konsumsi oksigen selama bekerja (Lunde, dkk., 2016), sehingga intensitas kerja dapat dilihat dari kapasitas aerobik maksimum $\left(\mathrm{VO}_{2 \max }\right) . \mathrm{VO}_{2 \max }$ berkaitan dengan kerja otot, semakin berat kerja otot konsumsi oksigen makin tinggi. Hasil pengukuran terhadap intensitas kerja menunjukkan bahwa terdapat korelasi antara iklim dengan $\mathrm{RHR}, \mathrm{VO}_{2 \max }, \% \mathrm{VO}_{2 \max }$, dan $\mathrm{RVO}_{2}$, dengan kata lain terdapat korelasi antara iklim dengan intensitas kerja.

$\mathrm{VO}_{2 \max }$ sangat dipengaruhi oleh kapasitas kardiovaskular dan pernapasan individu serta faktor-faktor pada tingkat jaringan lokal seperti kapilarisasi, enzim aerobik, distribusi jenis serat otot (Gunga, 2021). Oleh karena itu, selain dipengaruhi oleh faktor berat badan, jenis kelamin, dan usia, hasil $\mathrm{VO}_{2 \max }$ pada penelitian ini dapat disebabkan oleh faktor individu lain yaitu bahwa partisipan merupakan individu yang memiliki intensitas aktivitas fisik rendah-sedang, sehingga intensitas kerja pada percobaan ini termasuk dalam klasifikasi tinggi.

Tabel 3

Koefisien korelasi iklim terhadap beban kerja

\begin{tabular}{cccc}
\hline & Seluruh partisipan $(\mathrm{n}=30)$ & Pria $(\mathrm{n}=15)$ & Wanita $(\mathrm{n}=15)$ \\
\hline Energy Expenditure (kJ/ menit) & 0.300 & 0.292 & 0.683 \\
Relative $\mathrm{HR}$ & 0.775 & 0.697 & 0.810 \\
$\mathrm{VO}_{2} \max ($ liter/ menit) & 0.789 & 0.730 & 0.817 \\
\%VO $\mathrm{VO}_{2}$ max & 0.789 & 0.783 & 0.829 \\
Relative $\mathrm{VO}_{2}$ & 0.775 & 0.697 & 0.810 \\
\hline
\end{tabular}

Beberapa penelitian telah dilakukan untuk memodelkan beban kerja dan intensitas kerja. Sebagai contoh, perbedaan model estimasi energy expenditure Kamalakannan, dkk. (2007) dan Keytel, dkk. (2005) adalah pada parameter tinggi badan dan penggunaan $\mathrm{HR}_{\text {rest }}$. Penelitian ini tidak memperoleh korelasi antara iklim dan energy expenditure namun sebaliknya untuk $\% \mathrm{VO}_{2 \max }$, sedangkan $\mathrm{VO}_{2 \max }$ sangat dipengaruhi oleh kapasitas kardiovaskular. Terdapat kemungkinan bahwa model penentuan energy expenditure yang digunakan tidak sesuai dengan eksperimen ini. Oleh karena pada sebuah ekserimen perlu kajian yang lebih mendalam dalam penggunaan model estimasi energy expenditure, sehingga diperoleh model yang digunakan diharapkan sesuai dengan karakteristik pekerjaan. 


\section{KESIMPULAN}

Rata-rata indeks WBGT sebesar $31^{\circ} \mathrm{C}$ selama penelitian termasuk dalam kategori tinggi dan berrisiko heat stress. Beban kerja fisik dari aktivitas fisik yang dilakukan oleh pada eksperimen ini termasuk dalam kategori beban kerja tinggi/ berat. Pada penelitian ini tidak terdapat korelasi antara iklim dan beban kerja bila dilihat dari energy expenditure, namun demikian korelasi iklim terhadap beban kerja terjadi bila melihat intensitas kerja dari $\mathrm{VO}_{2 \max }, \% \mathrm{VO}_{2 \max }$, relative heart rate (RHR) dan relative oxygen uptake $\left(\mathrm{RVO}_{2}\right)$. Oleh karena itu dalam penentuan model estimasi energy expenditure perlu dikaji kesesuaian model dengan karakteristik pekerjaannya. Walaupun 30 menit beraktivitas dapat meningkatkan intensitas kerja sedang-tinggi, namun tidak cukup untuk memanaskan tubuh, sehingga tingkat penguapan yang terjadi tidak signifikan. Oleh karena penggunaan sweat rate dalam mengestimasi beban kerja fisik perlu waktu eksperimen yang mencukupi untuk mendapatkan tingkat penguapan yang dapat diukur. Dari penelitian pendahulu ini, perlu dilakukan penelitian lanjutan dengan durasi kerja yang lebih panjang, dan penelaahan terhadap model estimasi beban kerja yang sesuai.

\section{DAFTAR PUSTAKA}

American Conference of Govermental Industrial Hygienist. (2009). Guide to Occupational Exposure Values. American Conference of Govermental Industrial Hygienist.

Baker, L. B. (2017). Sweating Rate and Sweat Sodium Concentration in Athletes: A Review of Methodology and Intra/Interindividual Variability. Sports Medicine, 47 (Suppl 1), S111-S128.

Bedny, G., Karwowski, W., \& Seglin, M. (2001). A Heart Rate Evaluation Approach to Determine CostEffectiveness an Ergonomics Intervention. International Journal of Occupational Safety and Ergonomics, Vol. 7 No. 2, , 121-133.

Fan, X., Zhao, C., Luo, H., \& Zhang, W. (2019). Human Sweating Measurement. In R. S. Goonetilleke, \& W. Karwowski, Advances in Physical Ergonomics and Human Factors - Proceedings of the AHFE 2019 International Conference on Physical Ergonomics and Human Factors (pp. 157-174). Washington DC: Springer.

Gao, C., Kuklane, K., Östergren, P.-O., \& Kjellstrom, T. (2018). Occupational heat stress assessment and protective strategies in the context of climate change. International Journal of Biometeorology, Vol 16, 359-371.

Gunga, H.-C. (2021). Human Physiology in Extreme Environments, 2nd Edition. Academic Press-Elsevier Inc.

Hajizadeh, R., Golbabaei, F., Dehghan, S. F., Beheshti, M. H., Jafari, S. M., \& Taheri, F. (2016). Validating the Heat Stress Indices for Using In Heavy Work Activities in Hot and Dry Climates. Journal of Research in Health Sciences, Vol 16 (2), 90-95.

Helander, M. (2006). A Guide to Human Factors and Engineering. Florida: Taylod and Francis.

Holmér, I., \& Gavhed, D. (2007). Classification of metabolic and respiratory demands in fire fighting activity with extreme workloads. Applied Ergonomi, 38 (1), 45-52.

Hunt, A. P. (2011). Heat Strain, Hydration Status, and Symptoms of Heat Illness in Surface Mine Worker, Thesis. Queensland: Queensland University of Technology.

Iridiastadi, H., \& Yassierli. (2014). Ergonomi: Suatu Pengantar. Bandung: Remaja Rosda Karya.

Kamalakannan, B., Groves, W., \& Freivalds, A. (2007). Predictive Models for Estimating Metabolic Workload Based on Heart Rate and Physical Characteristic. The American Society of Safety Engineers Vol. 4 num. 1 .

Keytel, L., Goedecke, J., Noakes, T., Hiiloskorpi, H., \& Lambert, R. (2005). Prediction of Energy Expenditure form Heart Rate Monitoring During Submaksimal Exercise. Journal of Sport Sciences, Vol. 23(3), 289297.

Konz, S., \& Johnson, S. (2008). Work Design: Occupational Ergonomics. Boca Raton: CRC Press.

Kraemer, W. J., Fleck, S. J., \& Deschenes, M. R. (2012). Exercise Physiology: Integrating Theory and Application, 1st Ed. Lippincott Williams \& Wilkins.

Kroemer, K. H., \& Grandjean, E. (2009). Fitting the Task to the Human: A textbook of Occupational Ergonomic 5th ed. London: Taylor \& Francis.

Kroemer, K. H., Kroemer, H. J., \& Kroemer-Elbert, K. E. (2020). Engineering Physiology-Bases of Human Factors Engineering/ Ergonomics. 5th ed. . Springer. 
Lunde, L.-K., Koch, M., Veiersted, K. B., Moen, G.-H., Wærsted, M., \& Knardahl, S. (2016). Heavy PhysicalWork: Cardiovascular Load in Male ConstructionWorkers. Internatnional Journal of Environmental Research and Public Health, 13, 356.

Pawlak, H., \& Maksym, P. (2018). Modelling assessment of farmers workload. BIO Web of Conferences: Contemporary Research Trends in Agricultural Engineering, Volume 10, 02026.

Pettitt, R. W., Pettitt, C., Cabrera, C. A., \& Murray, S. R. (2007). A Theoretical Method of Using Heart Rate to Estimate Energy Expenditure During Exercise. International Journal of Sports Science \& Coaching, Vol. 2 (3), 319-327.

Roja, Z., Kalkis, H., Babris, S., Roja, I., Bokse, K., \& Ventins, A. (2020). Physical Workload Analysis in Processing Operations: Metal Processing Manufacturing. In R. S. Goonetilleke, \& W. Karwowski, Advances in Physical Ergonomics and Human Factors (pp. 14-21). Switzerland: Springer Nature .

Smith, J. W., Bello, M. L., \& Price, F. G. (2021). A Case-Series Observation of Sweat Rate Variability in Endurance-Trained Athletes. Nutrient, 13, 1807, 1807.

Søgaard, K., \& Sjøgaard, G. (2015). Physiological Bases of Work Assessment. In J. R. Wilson, \& S. Sharples, Evalluation of Human Work, 4th Ed. (pp. 419-445). CRC Press, Taylor \& Francis Group.

Tanaka, H., Monahan, K., \& Seals, D. (2001). Age-Predicted Maximal Heart Rate Revisited. Journal of the American College of Cardiology, Vo. 37 No. 1, 126-156.

Wahyuning, C. S., Salami, I. R., \& Sutalaksana, I. Z. (2017). Pengaruh Lingkungan Kerja Kabin Lokomotif Terhadap Tingkat Stres Dan Beban Kerja Mental Masinis Secara Fisiologis. Jurnal Sistem Teknik Industri (JSTI). 19 (1), , 20-29.

Wilson, T. E., \& Crandall, C. G. (2011). Effect of Thermal Stress on Cardiac Function. Exercise Sport Science Review, 39(1), 12-17.

Wu, H.-C., \& Wang, M.-J. J. (2002). Relationship between maximum acceptable work time and physical wokload. Ergonomic. Vol 45 (4), 280-289. 